
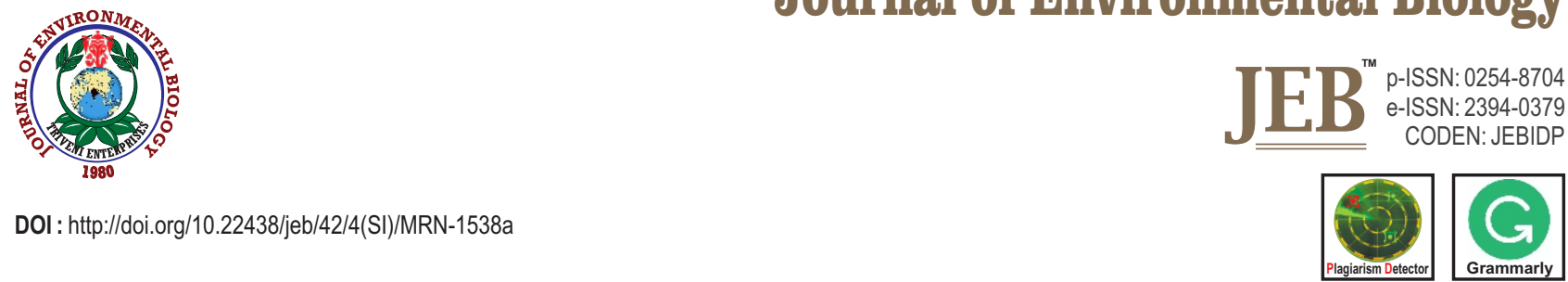

\title{
Probing cellulolytic yeast from forest ecosystem for the saccharification of Napier fodder biomass
}

\author{
M.G. Valliammai, N.O. Gopal ${ }^{\star}$ and R. Anandham \\ Department of Agricultural Microbiology, Tamil Nadu Agricultural University, Coimbatore-641 003, India \\ *Corresponding Author Email : nogopal@tnau.ac.in
}

\section{Abstract}

Aim: This study aimed to search for novel cellulolytic isolates with high cellulase titre for the production of fuels and chemicals.

Methodology: The yeast isolate YES5 isolated from the forest soil was screened for cellulase production. The cellulase activity of YES5 was optimized via RSM. The saccharification potential of YES5 using Napier biomass as substrate was evalauted.

Results: The maximum cellulase activity obtained after optimizing $\mathrm{pH}$, temperature, and incubation period was $35.70 \mathrm{U}$. A reliable statistical model was developed for maximizing the cellulase activity in YES5 Trichosporon asahii. The cellulase activity was $23.87 \mathrm{U}$, when carbon source in CMC medium was replaced by Napier biomass. The maximum saccharification potential of $33.15 \%$ was observed on $3^{\text {rd }}$ day.

Interpretation: The study of optimizing the media composition of Trichosporon asahii cellulase using Napier biomass, a natural source of carbon for maximizing the cellulase production via RSM, is first of its kind.
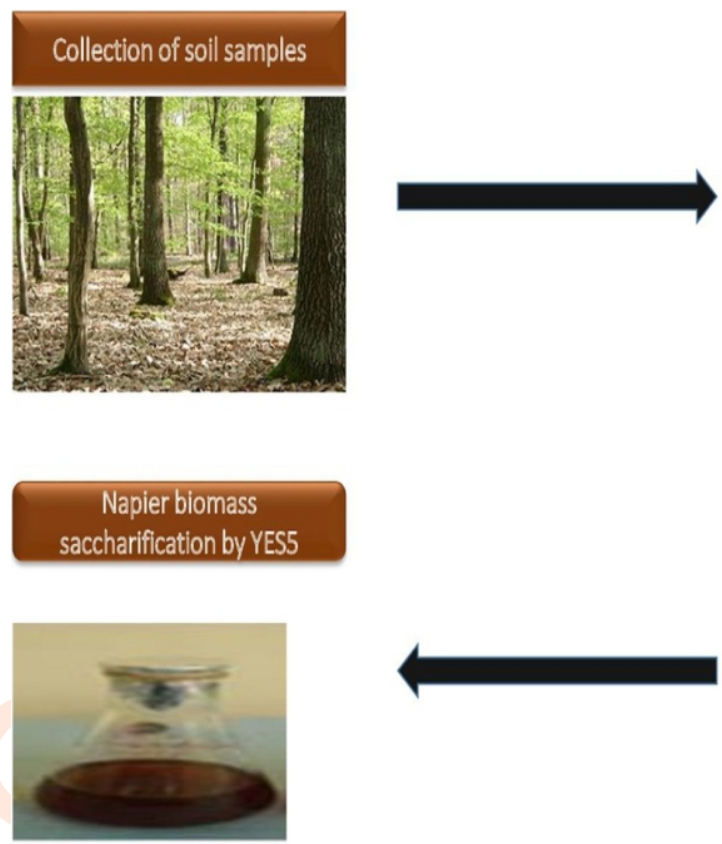

Key words: Cellulase, Napier biomass, Saccharification, Trichosporon asahii

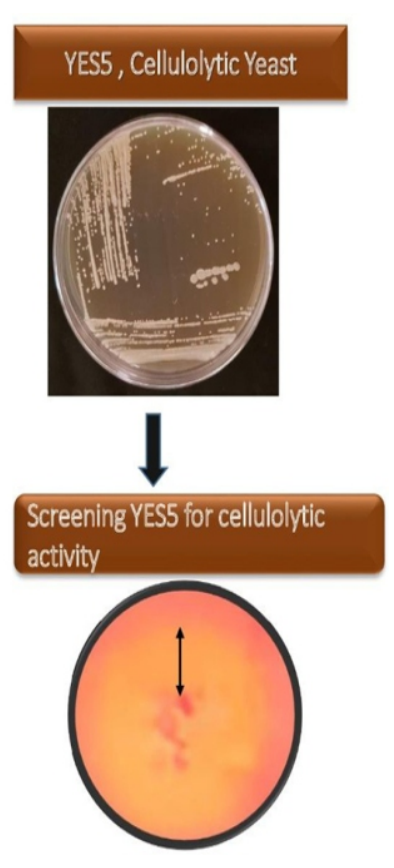

How to cite : Valliammai, M.G., N.O. Gopal and R. Anandham: Probing cellulolytic yeast from forest ecosystem for the saccharification of Napier fodder biomass. J. Environ. Biol., 42, 1152-1161 (2021). 


\section{Introduction}

As the world population is increasing at an alarming rate, the energy consumption ratio is also rising. Forests and people are tightly coupled in this country (Baboo et al., 2017). Studies have reported that millions of people reside within or close to forests and harvest forest products (Davidar et al., 2010; Gosain et al., 2015; Bargali and Bargali 2016). The activities occurring in the forests include exploitation through commercial logging, seasonally set forest fires, fuel wood removal, charcoal production, cattle grazing, pruning and land clearing for agricultural activities (Bhuyan et al., 2003; Bargali et al., 2019). These disturbances have changed the forest composition, structure and reduced species diversity as well as resources by restricting size of forest patches (Sagar and Singh 2005; Karki et al., 2017). Continued increase in human population together with livestock populations, the pressure on these forests has increased tremendously and consequently resulting in reduced carrying capacity of these forests (Bargali et al., 2018; Manral et al., 2020). The increasing population and reduced resources have increased the gap between demand and supply of ecosysytem services (Bargali etal., 1992a, b; 1993; Gosain etal., 2015).

Nonrenewable resources may not be sufficient to meet out the energy requirement of the society so there is a swift in the utilization of resources from nonrenewable to renewable for the production of value added compounds (Gaurav et al., 2017; Valliammai et al., 2021). The environment concerning factors which have paved the path for the production of microbial cellulases are global warming and greenhouse effects (Vanhala et al., 2016). In the current era, microbes play a key role in biomass conversion (Shariq and Sohail, 2018). The effective roles contributed by microbes in bio refinery concept are pretreatment, hydrolysis, detoxification and fermentation. The performance of microbes varies according to the desired yield (Dien et al., 2003). Application of microbes or microbial enzymes for the pretreatment of lignocellulosic biomass is gaining momentum in the industry. Cellulases are inducible enzymes which can be produced by microbes during their growth on cellulosic material (Lee and Koom, 2001). Structurally fungal cellulases are simpler than bacterial cellulase systems (Artzi et al., 2015).

Different kinds of microbes involved in the production of cellulase are aerobic, anaerobic, mesophilic or thermophilic. Among them, Clostridium, Cellulomonas, Thermomonospora, Trichoderma and Aspergillus. They are the most extensively studied cellulase producers (Sukumaran et al., 2005). Trichosporon asahii belongs to genus Trichosporon, a genus of anamorphic fungi of family Trichosporonaceae. Limited studies are available with regard to cellulolytic potential of Trichosporon asahii. The predominant yeast species found in waste biomass conversion to bioproducts reported so far are Candida tropicalis, Candida intermedia, Candida parapsilosis, Pichia guilliermondii, Saccharomyces cerevisiae and Trichosporon asahii (Schwan et al., 2007). Yeasts like Candida tropicalis are involved saccharification of rice straw, corn-cob (Guo et al., 2013). Exploring the nature of cellulase activity of Trichosporon asahii in Napier (Pennisetum purpureum) fodder biomass conversion into ethanol is first of its kind. Cellulase activity can be observed in diverse group of microbes while utilizing cellulosic materials (Lu et al., 2010). Cellulase activity in microbes can be improved by nutritional and process parameters during fermentation (Rasul et al., 2015). Response surface methodology is an efficient technique utilized for optimization of fermentation processes (Valliammai et al., 2020). Mathematical models are proven tools in the optimisation of process parameters during fermentation (Imamoglu and Sukan, 2013). Napier fodder (Pennisetum purpureum) is a fast growing perennial crop widely observed in tropical and subtropical regions of the world. It has a higher yield per unit area and the biomass productivity is also commendable (Woodard and Prine, 1993) High cellulose content in Napier fodder makes it a promising substrate for the biobased economy. In this study, yeast YES5 Trichosporon asahii was isolated from the forest soil sample. The cellulase activity of YES5 using Napier biomass as carbon source was optimized via RSM. The study of standardising the cellulase activity of YES5 for the Napier biomass saccharification is a novel approach.

\section{Materials and Methods}

Isolation and screening of cellulolytic yeasts from forest ecosystem: Forest soil samples were collected from the Eastern Ghats region (N 10.29 363॰) (E $77.70674 \circ$ ) of Thandikudi, Tamil Nadu, India. Isolation was initiated via serial dilution technique followed by pour plating. Ten gram of soil sample was suspended in $99 \mathrm{ml}$ of water and used for isolation of cellulolytic yeast using carboxymethyl cellulose agar medium and incubated at $28^{\circ} \mathrm{C}$ for 2-3 days (Hendricks et al., 1995). The appeared colonies were purified and then screened for cellulase activity via congo-red agar medium (Hankin and Anagnostakis, 1977). Among different yeast isolates, YES5 showed maximum cellulase activity and, hence, was selected for further study.

Identification of cellulolytic yeast isolate YES5: Cellulolytic yeast isolate was cultivated in CMC agar medium, and DNA was extracted (Harju et al., 2004). Nearly-full length 18 S rRNA gene was amplified from the genomic DNA of YES5 isolate using a forward primer as NL-1 (5' GCA TAT CAA TAA GCG GAG GAA AAG 3') and reverse primer as NL-4 (5' GGT CCG TGT TTCAAA GAC GG 3') primers. The PCR product was sequenced through $\mathrm{ABI}$ prism terminator cycle sequencing ready reaction kit, and electrophoresis of the products were carried out on an Applied Biosystems (Model 3100) automated sequencer (M/s. Yaazh Genomics, Coimbatore, India). Isolate YES5 exhibited $96.96 \%$ similarity to Trichosporon asahii MN368077. The 18S rRNA gene sequence was submitted to $\mathrm{NCBI}$ with accession number MK640632. 
Cellulase assay: Trichosporon asahii YES5 was cultivated in $\mathrm{CMC}$ broth at $28^{\circ} \mathrm{C}$ for 2 days, and the culture supernatant was collected by centrifugating at $13000 \mathrm{rpm}$ for $8 \mathrm{~min}$. A $200 \mu \mathrm{l}$ of culture supernatant was mixed with $200 \mu$ of $1 \%$ CMC solution and incubated at $50^{\circ} \mathrm{C}$ for $30 \mathrm{~min}$. DNS reagent was added and incubated at $100^{\circ} \mathrm{C}$ for $10 \mathrm{~min}$. The absorbance was read at 575 nm against reagent blank. In this study, one unit of enzyme activity refers to the release of $1 \mu \mathrm{mol}$ of reducing sugar per min per $\mathrm{ml}$ (Wood and Bhat, 1988).

Effect of carbon source in cellulase activity: The influence of different carbon sources was determined by substituting the carbon sources viz., fructose, galactose, sucrose, lactose, starch, and $\mathrm{CMC}$ individually in place of carbon source in the medium. About $5 \mu$ of 24 -hr-old culture $\left(7 \times 10^{8} \mathrm{CFU} \mathrm{ml}{ }^{-1}\right)$ was inoculated in $100 \mathrm{ml}$ medium supplemented with different carbon sources and incubated at $28^{\circ} \mathrm{C}$ for $24 \mathrm{hr}$. The culture supernatant from each source was collected and assayed for cellulase activity (Wood and Bhat, 1988).

Effect of $\mathrm{pH}$ and temperature on cellulase activity: Cellulase activity was determined at different incubation period, temperature and initial $\mathrm{pH}$. Five microliter of 24 -hr-old culture $(7 \mathrm{x}$ $10^{8} \mathrm{CFU} \mathrm{ml}{ }^{-1}$ ) of YES5 Trichosporon asahii was inoculated into $\mathrm{CMC}$ broth and incubated at $28^{\circ} \mathrm{C}$ for different time period $(5$ days). The day at which maximum cellulase activity observed was considered for further optimizing the $\mathrm{pH}$ range (4.5 to 8.5 with an increment of 1.0) and temperature range $\left(25^{\circ} \mathrm{C}\right.$ to $40^{\circ} \mathrm{C}$ with an increment of $5^{\circ} \mathrm{C}$ ).

Statistical optimization of cellulase activity using Napier biomass as a carbon source: For maximizing cellulase production, RSM was employed with CCD. The selected parameters and their range are provided in Table1. A total of 78 experiments were performed with different combinations (Table 2). Cellulase assay was performed as described earlier. The response value $(Y)$ in each trial is the average of duplicates. The design expert trial version 12 was used for the development of design matrix and statistical analysis of the data. Regression analysis was performed to estimate the response function as a second-order polynomial (Wang et al., 2011):

$$
Y=\beta 0+\ldots \beta i X i+\_\beta i j X i X j+\_\beta i i X i 2
$$

Where, $Y$ is the predicted response, $\beta 0$ is the intercept term, $\beta \mathrm{i}$ is the linear coefficient, $\beta \mathrm{ij}$ is the quadratic coefficient and $\beta$ ii is the interaction coefficient. Analysis of variance (ANOVA) was adopted to know the significance of the model. The quality of polynomial model equation was judged statistically through coefficient of determination $\left(R^{2}\right)$ and adjusted $R^{2}$. Overall significance was evaluated through Fishers test. Threedimensional plots illustrated the response for each interaction. In order to validate the model predicted by the software, experiments were performed in shake-flasks. Physical parameters were kept at optimum levels. Cellulase assay was performed as described earlier.

Compositional analysis of Napier biomass: The compositional analysis of Napier biomass was determined as per the standard protocols of NREL, 2004 (Sluiter et al., 2012).

Saccharification of Napier biomass: The leftover Napier fodder in the field was collected and dried in a tunnel drier to get a brittle texture. The dried powder was sieved through a $50 \mu$ sieve. One gram of powder was added to $100 \mathrm{ml}$ of medium containing optimized levels of nitrogen source and mineral salts $\left(1 \mathrm{~g} \mathrm{~K}_{2} \mathrm{HPO}_{4}\right.$, $0.5 \mathrm{~g} \mathrm{MgSO}_{4}, 0.5 \mathrm{gNaCl}, 1.0 \mathrm{~g}$ peptone, $\left.0.25 \mathrm{~g}\left(\mathrm{NH}_{4}\right) 2 \mathrm{SO}_{4}\right)$ and autoclaved at $110^{\circ} \mathrm{C}, 15 \mathrm{lbs}$ pressure for $20 \mathrm{~min} .5 \mu \mathrm{l}$ of $24 \mathrm{~h}$ old culture $\left(7 \times 10^{8} \mathrm{CFU} \mathrm{ml}{ }^{-1}\right)$ Trichosporon asahii was inoculated and allowed for saccharification at $30^{\circ} \mathrm{C}$ and $120 \mathrm{rpm}$ for 5 days. Samples were taken at an interval of $24 \mathrm{hr}$ to monitor sugar release. The experiments were performed in triplicates. The percentage of saccharification was noted as per the standard protocols of NREL, 2004 (Uma et al., 2010).

\section{Results and Discussion}

The yeast isolate YES5 was creamy, glossy colonies with a cell morphology of globose shape present singly, multilateral budding with ascospores. The isolate YES5 was identified based on 18S rRNA sequencing as Trichosporon asahii. Certain yeast strains like Pichia stipitis, Saccharomyces cerevisiae, and Kluyveromyces fagilis were reported as good ethanol producers from different types of sugars (Mussatto et al., 2012). Though there are many cellulolytic organisms, researchers are still exploring novel microbes for biomass conversion into value-added products. A clear zone of hydrolysis was observed around the colony of isolate YES5 suggesting cellulose hydrolyzing nature of YES5. (Fig. 1).

The carbon sources used in the assay were fructose, galactose, sucrose, lactose, starch, and CMC. The YES5 yeast

Table 1: Factors employed in the RSM experiment for optimum cellulase activity

\begin{tabular}{lllll}
\hline Factors & + alpha & - alpha & Low value & High value \\
\hline Napier biomass & 2.174 & 17.825 & 5 & 15 \\
Peptone & 2.174 & 17.825 & 5 & 15 \\
$\mathrm{NaCl}$ & 0.043 & 0.356 & 0.1 & 0.3 \\
$\mathrm{MgSO}$ & 0.534 & 0.15 & 0.45 \\
$\left(\mathrm{NH}_{4}\right)_{2} \mathrm{SO}_{4}$ & 0.065 & 0.356 & 0.1 & 0.3 \\
\hline
\end{tabular}


Table 2: Optimization of nutrient components for maximum cellulase activity

\begin{tabular}{|c|c|c|c|c|c|c|c|}
\hline $\begin{array}{l}\text { Factor } 1 \\
\text { A:Napier } \\
\text { biomass }\end{array}$ & $\begin{array}{l}\text { Factor } 2 \\
\text { B:Peptone }\end{array}$ & $\begin{array}{l}\text { Factor } 3 \\
\text { C:Dipotassium } \\
\text { hydrogen } \\
\text { phosphate }\end{array}$ & $\begin{array}{l}\text { Factor } 4 \\
\text { D:Magnesium } \\
\text { sulphate }\end{array}$ & $\begin{array}{l}\text { Factor } 5 \\
\text { E:Ammonium } \\
\text { sulphate }\end{array}$ & $\begin{array}{l}\text { Factor } 6 \\
\text { F:Sodium } \\
\text { chloride }\end{array}$ & $\begin{array}{l}\text { Observed } \\
\text { Cellulase } \\
\text { activity }\left(\mathrm{U} \mathrm{ml}^{-1}\right)\end{array}$ & $\begin{array}{l}\text { Predicted } \\
\text { Cellulase } \\
\text { activity }\left(\mathrm{U} \mathrm{ml}^{-1}\right)\end{array}$ \\
\hline 15 & 15 & 0.1 & 0.15 & 0.3 & 0.5 & 19.03 & 19.66 \\
\hline 5 & 15 & 0.1 & 0.15 & 0.3 & 1.5 & 17.79 & 16.43 \\
\hline 10 & 10 & 0.2 & 0.3 & 0.2 & 1 & 23.36 & 23.87 \\
\hline 5 & 15 & 0.1 & 0.15 & 0.1 & 0.5 & 17.69 & 16.16 \\
\hline 15 & 15 & 0.3 & 0.45 & 0.1 & 1.5 & 19.25 & 19.04 \\
\hline 5 & 15 & 0.3 & 0.15 & 0.3 & 0.5 & 17.38 & 16.67 \\
\hline 5 & 5 & 0.3 & 0.45 & 0.1 & 0.5 & 15.82 & 15.53 \\
\hline 15 & 5 & 0.3 & 0.15 & 0.3 & 0.5 & 16.19 & 16.38 \\
\hline 5 & 15 & 0.3 & 0.45 & 0.3 & 1.5 & 15.92 & 16.02 \\
\hline 10 & 10 & 0.2 & 0.3 & 0.2 & 0.217458 & 23.87 & 23.55 \\
\hline 10 & 10 & 0.2 & 0.3 & 0.2 & 1.78254 & 23.45 & 23.50 \\
\hline 15 & 5 & 0.3 & 0.45 & 0.1 & 0.5 & 17.02 & 17.19 \\
\hline 5 & 15 & 0.3 & 0.15 & 0.1 & 1.5 & 15.88 & 16.09 \\
\hline 5 & 5 & 0.3 & 0.15 & 0.1 & 0.5 & 15.04 & 15.37 \\
\hline 5 & 15 & 0.1 & 0.45 & 0.3 & 0.5 & 15.77 & 16.05 \\
\hline 5 & 5 & 0.3 & 0.15 & 0.3 & 0.5 & 15.00 & 14.91 \\
\hline 15 & 5 & 0.1 & 0.15 & 0.3 & 1.5 & 17.82 & 17.59 \\
\hline 15 & 15 & 0.3 & 0.45 & 0.3 & 0.5 & 19.89 & 19.55 \\
\hline 5 & 15 & 0.3 & 0.45 & 0.3 & 0.5 & 15.89 & 16.65 \\
\hline 5 & 5 & 0.3 & 0.45 & 0.1 & 1.5 & 15.02 & 15.31 \\
\hline 15 & 5 & 0.3 & 0.15 & 0.1 & 0.5 & 17.26 & 16.87 \\
\hline 17.8254 & 10 & 0.2 & 0.3 & 0.2 & 1 & 18.27 & 18.27 \\
\hline 5 & 5 & 0.1 & 0.45 & 0.3 & 0.5 & 15.05 & 14.67 \\
\hline 5 & 15 & 0.3 & 0.45 & 0.1 & 0.5 & 17.21 & 16.56 \\
\hline 10 & 10 & 0.2 & 0.0652373 & 0.2 & 1 & 22.18 & 22.22 \\
\hline 5 & 5 & 0.1 & 0.15 & 0.3 & 0.5 & 15.05 & 15.07 \\
\hline 15 & 5 & 0.3 & 0.15 & 0.3 & 1.5 & 16.87 & 16.88 \\
\hline 10 & 10 & 0.2 & 0.3 & 0.0434915 & 1 & 23.45 & 22.84 \\
\hline 15 & 5 & 0.1 & 0.15 & 0.1 & 0.5 & 17.01 & 17.18 \\
\hline 15 & 15 & 0.1 & 0.15 & 0.1 & 1.5 & 18.94 & 19.35 \\
\hline 10 & 2.17458 & 0.2 & 0.3 & 0.2 & 1 & 16.93 & 17.73 \\
\hline 5 & 5 & 0.1 & 0.45 & 0.1 & 1.5 & 15.00 & 14.97 \\
\hline 15 & 5 & 0.1 & 0.45 & 0.1 & 1.5 & 17.01 & 17.27 \\
\hline 15 & 15 & 0.1 & 0.15 & 0.1 & 0.5 & 19.32 & 19.30 \\
\hline 15 & 15 & 0.3 & 0.15 & 0.3 & 1.5 & 19.44 & 19.39 \\
\hline 5 & 5 & 0.3 & 0.15 & 0.1 & 1.5 & 16.59 & 15.48 \\
\hline 15 & 5 & 0.3 & 0.45 & 0.1 & 1.5 & 17.01 & 17.26 \\
\hline 15 & 5 & 0.1 & 0.45 & 0.3 & 0.5 & 16.98 & 16.66 \\
\hline 15 & 15 & 0.1 & 0.15 & 0.3 & 1.5 & 19.24 & 19.82 \\
\hline 15 & 15 & 0.3 & 0.15 & 0.3 & 0.5 & 19.99 & 19.42 \\
\hline 15 & 5 & 0.3 & 0.45 & 0.3 & 0.5 & 16.83 & 16.62 \\
\hline 10 & 10 & 0.0434915 & 0.3 & 0.2 & 1 & 23.22 & 22.51 \\
\hline 15 & 5 & 0.1 & 0.45 & 0.1 & 0.5 & 16.78 & 17.02 \\
\hline 5 & 5 & 0.3 & 0.45 & 0.3 & 1.5 & 15.02 & 14.88 \\
\hline 15 & 15 & 0.3 & 0.45 & 0.1 & 0.5 & 19.06 & 19.49 \\
\hline 15 & 5 & 0.3 & 0.15 & 0.1 & 1.5 & 17.27 & 17.27 \\
\hline 2.17458 & 10 & 0.2 & 0.3 & 0.2 & 1 & 14.58 & 14.31 \\
\hline 5 & 5 & 0.1 & 0.45 & 0.1 & 0.5 & 15.02 & 14.99 \\
\hline 10 & 10 & 0.2 & 0.3 & 0.2 & 1 & 23.43 & 23.87 \\
\hline 5 & 15 & 0.3 & 0.45 & 0.1 & 1.5 & 16.22 & 15.82 \\
\hline 5 & 15 & 0.3 & 0.15 & 0.3 & 1.5 & 16.11 & 16.36 \\
\hline 15 & 15 & 0.1 & 0.45 & 0.3 & 0.5 & 19.05 & 19.31 \\
\hline
\end{tabular}


Table 2: Optimization of nutrient components for maximum cellulase activity

\begin{tabular}{|c|c|c|c|c|c|c|c|}
\hline $\begin{array}{l}\text { Factor } 1 \\
\text { A:Napier } \\
\text { biomass }\end{array}$ & $\begin{array}{l}\text { Factor } 2 \\
\text { B:Peptone }\end{array}$ & $\begin{array}{l}\text { Factor } 3 \\
\text { C:Dipotassium } \\
\text { hydrogen }\end{array}$ & $\begin{array}{l}\text { Factor } 4 \\
\text { D:Magnesium } \\
\text { sulphate }\end{array}$ & $\begin{array}{l}\text { Factor } 5 \\
\text { E:Ammonium } \\
\text { sulphate }\end{array}$ & $\begin{array}{l}\text { Factor } 6 \\
\text { F:Sodium } \\
\text { chloride }\end{array}$ & $\begin{array}{l}\text { Observed } \\
\text { Cellulase } \\
\text { activity }\left(\mathrm{U} \mathrm{ml}^{-1}\right)\end{array}$ & $\begin{array}{l}\text { Predicted } \\
\text { Cellulase } \\
\text { activity }\left(\mathrm{U} \mathrm{ml}^{-1}\right)\end{array}$ \\
\hline 15 & 5 & 0.1 & 0.45 & 0.3 & 1.5 & 16.92 & 17.02 \\
\hline 15 & 15 & 0.3 & 0.45 & 0.3 & 1.5 & 19.04 & 19.20 \\
\hline 10 & 17.8254 & 0.2 & 0.3 & 0.2 & 1 & 21.34 & 20.27 \\
\hline 10 & 10 & 0.2 & 0.534763 & 0.2 & 1 & 22.12 & 21.81 \\
\hline 5 & 15 & 0.3 & 0.15 & 0.1 & 0.5 & 15.17 & 16.50 \\
\hline 5 & 5 & 0.1 & 0.45 & 0.3 & 1.5 & 15.02 & 14.75 \\
\hline 5 & 15 & 0.1 & 0.45 & 0.3 & 1.5 & 15.08 & 15.60 \\
\hline 15 & 15 & 0.1 & 0.45 & 0.3 & 1.5 & 19.67 & 19.14 \\
\hline 5 & 5 & 0.1 & 0.15 & 0.1 & 1.5 & 15.06 & 15.62 \\
\hline 15 & 15 & 0.3 & 0.15 & 0.1 & 1.5 & 19.02 & 19.15 \\
\hline 15 & 5 & 0.1 & 0.15 & 0.3 & 0.5 & 16.94 & 16.91 \\
\hline 5 & 5 & 0.1 & 0.15 & 0.3 & 1.5 & 15.04 & 15.48 \\
\hline 5 & 5 & 0.3 & 0.45 & 0.3 & 0.5 & 15.08 & 14.99 \\
\hline 15 & 15 & 0.1 & 0.45 & 0.1 & 0.5 & 19.03 & 19.03 \\
\hline 15 & 5 & 0.1 & 0.15 & 0.1 & 1.5 & 18.68 & 17.77 \\
\hline 5 & 5 & 0.3 & 0.15 & 0.3 & 1.5 & 15.09 & 15.12 \\
\hline 5 & 5 & 0.1 & 0.15 & 0.1 & 0.5 & 15.02 & 15.32 \\
\hline 10 & 10 & 0.2 & 0.3 & 0.356508 & 1 & 22.43 & 22.77 \\
\hline 5 & 15 & 0.1 & 0.45 & 0.1 & 1.5 & 15.05 & 15.18 \\
\hline 15 & 15 & 0.1 & 0.45 & 0.1 & 1.5 & 18.85 & 18.76 \\
\hline 15 & 5 & 0.3 & 0.45 & 0.3 & 1.5 & 16.75 & 16.79 \\
\hline 5 & 15 & 0.1 & 0.45 & 0.1 & 0.5 & 15.10 & 15.73 \\
\hline 10 & 10 & 0.356508 & 0.3 & 0.2 & 1 & 22.16 & 22.60 \\
\hline 5 & 15 & 0.1 & 0.15 & 0.3 & 0.5 & 16.01 & 16.55 \\
\hline 15 & 15 & 0.3 & 0.15 & 0.1 & 0.5 & 19.28 & 19.28 \\
\hline 5 & 15 & 0.1 & 0.15 & 0.1 & 1.5 & 15.02 & 15.93 \\
\hline
\end{tabular}

Table 3: Cellulolytic potential of Trichosporon asahii YES5 in synthetic and natural source of carbon

\begin{tabular}{|c|c|c|c|c|}
\hline Constant parameters & Variable parameters & Range & Optimum & Maximum activity \\
\hline $\begin{array}{l}\text { Basal medium+ Incubation } \\
\text { time+ Temperature+ } \mathrm{pH}\end{array}$ & Synthetic carbon sources & & CMC & $21.23 \mathrm{U} \mathrm{m}^{-1}$ \\
\hline $\begin{array}{l}\text { Basal medium }+\mathrm{CMC}+ \\
\text { Temperature }+\mathrm{pH}\end{array}$ & Incubation time & $1-5$ days & $3^{\text {rd }}$ day & $29.90 \mathrm{U} \mathrm{ml}^{-1}$ \\
\hline $\begin{array}{l}\text { Basal medium + } \mathrm{CMC}+\text { Optimum } \\
\text { Incubation Time+ } \mathrm{pH}\end{array}$ & Temperature & $25-40 \cdot C$ & $30 \cdot \mathrm{C}$ & $35.70 \mathrm{U} \mathrm{ml}^{-1}$ \\
\hline $\begin{array}{l}\text { Basal medium + CMC+ Optimum } \\
\text { Incubation Time+ Optimum } \\
\text { temperature }\end{array}$ & $\mathrm{pH}$ & $4.5-8.5$ & 6.5 & $34.49 \mathrm{U} \mathrm{ml}^{-1}$ \\
\hline $\begin{array}{l}\text { Optimum Incubation } \\
\text { Time+ Optimum }\end{array}$ & Napier biomass & $2.174-17.825 \mathrm{gl}^{-1}$ & $10 \mathrm{gl}^{-1}$ & \\
\hline Temperature+ & Peptone & $2.174-17.825 \mathrm{gl}^{-1}$ & $10 \mathrm{gl}^{-1}$ & 23.87 \\
\hline Optimum pH & $\begin{array}{l}\mathrm{NaCl} \\
\mathrm{MgSO}_{4} \\
\left(\mathrm{NH}_{4}\right) 2 \mathrm{SO}_{4} \\
\mathrm{~K}_{2} \mathrm{HPO}_{4}\end{array}$ & $\begin{array}{l}0.043-0.356 \mathrm{gl}^{-1} \\
0.065-0.534 \mathrm{gl}^{-1} \\
0.043-0.356 \mathrm{gl}^{-1} \\
0.2174-1.7825 \mathrm{gl}^{-1}\end{array}$ & $\begin{array}{l}0.2 \mathrm{gl}^{-1} \\
0.3 \mathrm{gl}^{-1} \\
0.2 \mathrm{gl}^{-1} \\
0.217 \mathrm{gl}^{-1}\end{array}$ & $\mathrm{Uml}^{-1}$ \\
\hline
\end{tabular}

isolate showed a positive response towards all the tested carbon sources, however, the impact of CMC as a source of carbon showed much higher cellulase activity compared to other carbon sources. The cellulase activity of YES5 isolate using CMC as a substrate was 21.22 U. (Fig. 2). Lignocellulosic biomass acts as a source of carbon for the microorganisms during the fermentation process (Battaglia et al., 2011). The most important carbon source in biomass is cellulose and is converted into value-added 
products by the enzyme cellulase (Lu et al., 2013; Valliammai et al., 2021). Maximum cellulase activity was observed by optimizing the factors like incubation period, temperature, and pH. (Fig. 3A-C). The cellulase activity was observed throughout the incubation period; however, it was maximum on day 3 (29.90 U). Though cellulase activity was observed $25-45^{\circ} \mathrm{C}$, the optimum temperature for obtaining maximum cellulase activity was $30^{\circ} \mathrm{C}$ $(35.70 \mathrm{U})$. While increasing the temperature, cellulase activity decreased. Among the various $\mathrm{pH}$ tested, the optimum $\mathrm{pH}$ for cellulase activity was 6.5 (34.498 U). The cellulase activity was minimum at $\mathrm{pH}$ of 4.5 . The factors influencing cellulase activity were carbon sources, $\mathrm{pH}$, temperature, incubation period. This study highlights that $\mathrm{CMC}$ as a source of carbon was ideal for exhibiting maximum cellulase activity when compared with other carbon sources. CMC plays a significant positive impact on cellulase production by cellulolytic microbe (Deka et al., 2011). The optimum $\mathrm{pH}$ for the production of cellulase by YES5 was 6.5.Cellulase activity is dependent on temperature and $\mathrm{pH}$ (Tai et al., 2004). The $\mathrm{pH}$ of the medium has a strong influence on the enzymatic processes and the mobility of components across the cell membrane (Moon and Parulekar, 1991). The most popular design employed for optimization of cellulose prduction is Response Surface Methodologies (Queen et al., 2002). RSM offers statistical predictions and actual observation (Singh and Kaur, 2012). For optimising the medium composition for cellulase activity, a natural source of carbon (powdered Napier biomass) was substituted in the place of synthetic carbon source. The combination which the maximum cellulase activity was observed using a natural source of carbon was observed (Table2). The second-order polynomial equation for cellulase activity is as follows:

$$
Y=+23.87++1.26 A+0.8132 B+0.0277 C-0.1295 D-
$$
$0.0195 E-0.0135 F+0.3186 A B-0.0902 A C+0.0392 A D-$

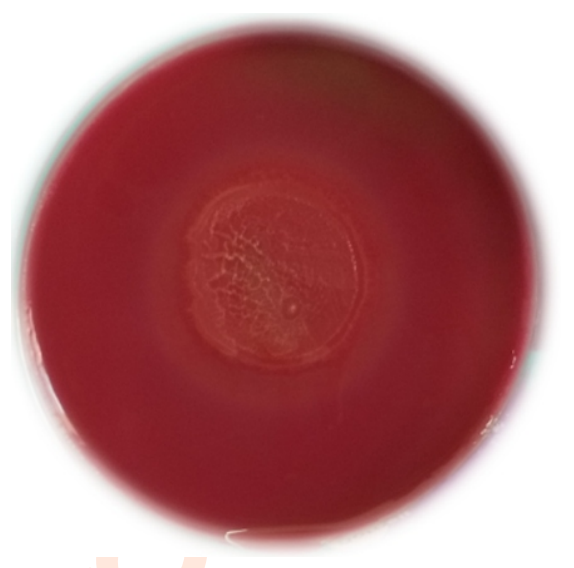

Fig. 1: Trichosporon asahii YES5 showing cellulolytic activity. The zone around YES5 colony indicates cellulose hydrolyzing nature.

$0.0083 A E+0.0705 A F+0.0727 B C-0.0255 B D+0.1589 B E-$ $0.1317 \mathrm{BF}+0.1208 \mathrm{CD}-0.0548$ CE-0.0461CF-0.0192DE$0.0817 D F+0.0258 E F-3.10 A^{2}-1.99 B^{2}-0.5386 C^{2}-0.7591 D^{2}-$ $0.4366 \mathrm{E}^{2}-0.1426 \mathrm{~F}^{2}$; where $\mathrm{Y}$ is the cellulase activity $(\mathrm{U} / \mathrm{ml})$ and $A, B, C, D, E$ and $F$ are the test variables. The ANOVA results convey that the model was highly significant and it was obvious with F-value as 48.06 and $<0.0001 \mathrm{p}$-value. The model showed insignificant lack of fit (19.14). The F, P and lack of fit values indicate that the conducted experiments were in good fit. The predicted $R^{2} 0.9046$ was par with the Adjusted $R^{2} 0.9429$. The $R^{2}$ value was 0.9629 , so the model could explain $96 \%$ of total variation. Pure error was 0.0025 , which indicated the good reproducibility of the experiments. 3D plots were obtained, which conveyed the best combination of parameters where the cellulase activity was optimum (Fig. 4)

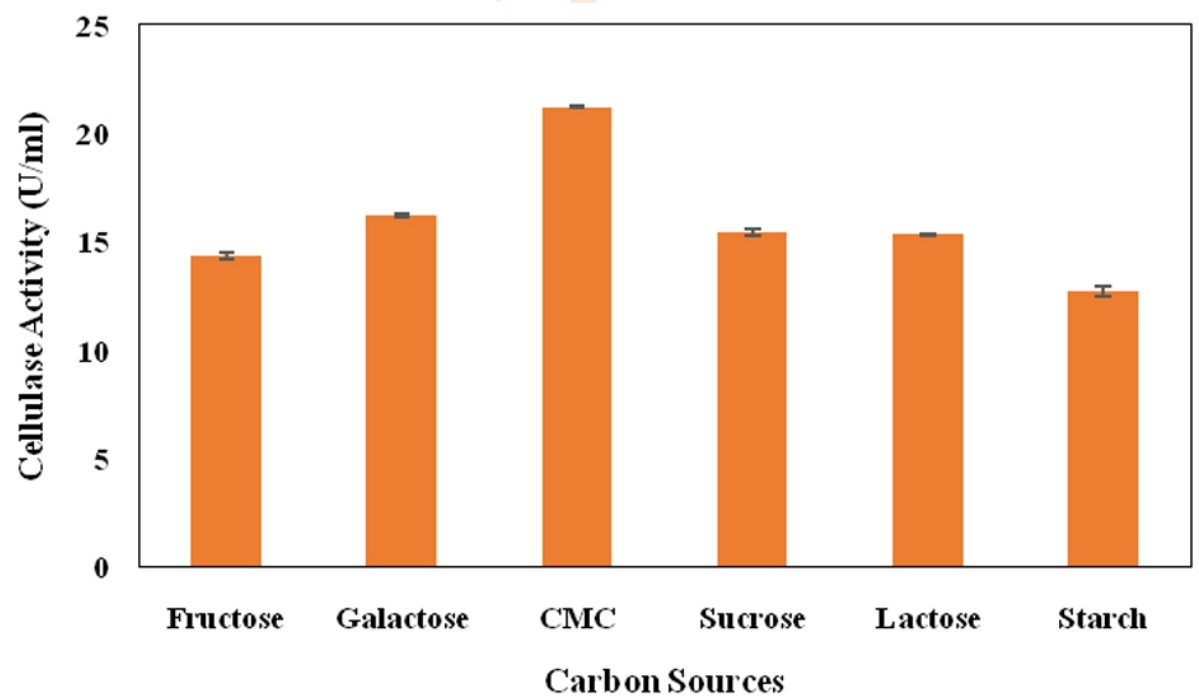

Fig. 2: Effect of carbon sources on cellulase activity of yeast isolate Trichosporon asahii YES5. The yeast isolate YES5 was cultured in different mono, di and polysaccharide sources and cellulase assay was done in triplicate. The values are depicted along with standard deviation. 

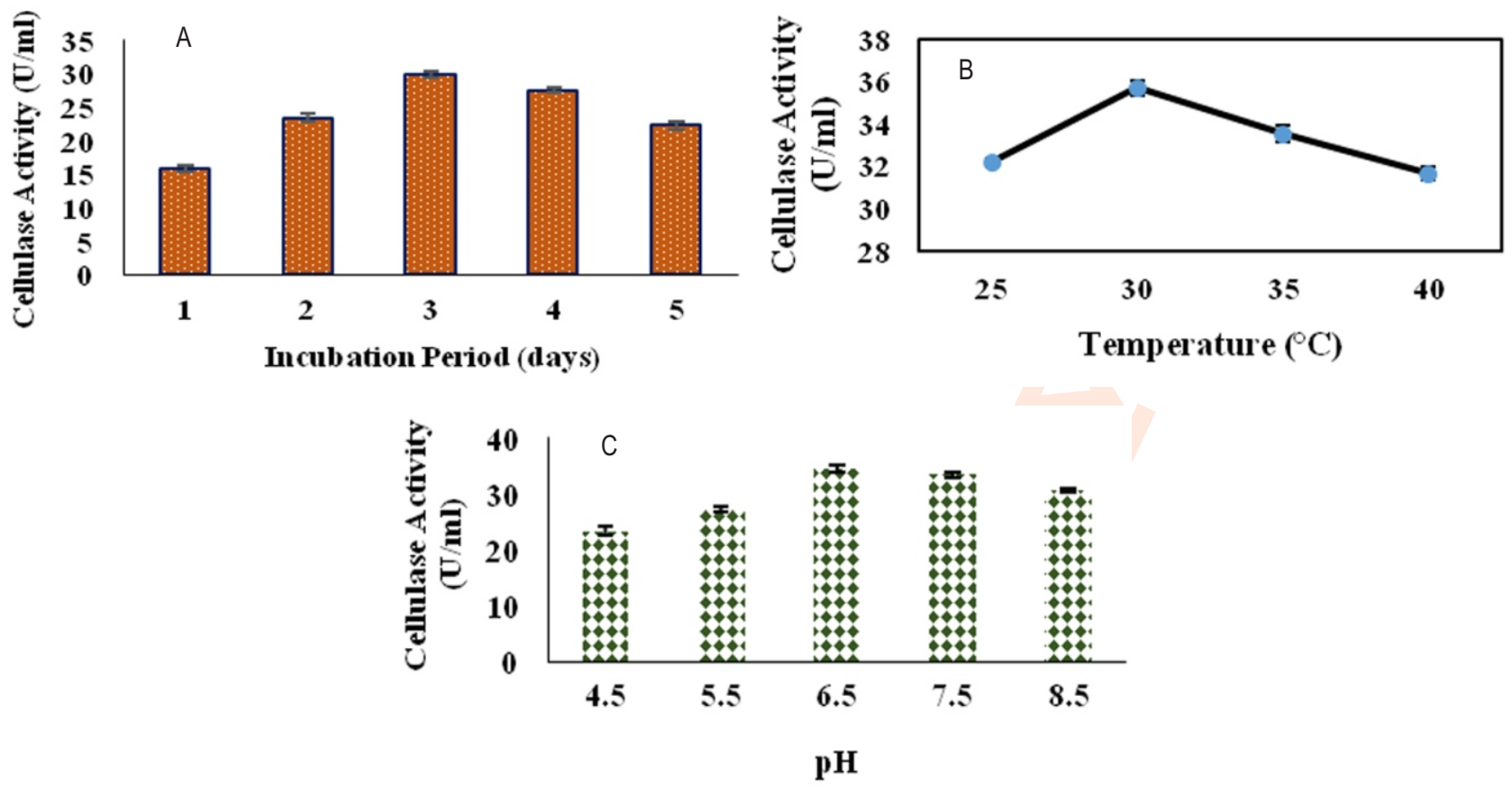

Fig. 3: The effect of process parameters on cellulase assay of Trichosporon asahii YES5: (A) Incubation period, (B) Temperature and (C) pH. The assay values was done in triplicate and presented along with standard deviation.

The maximum cellulase activity predicted by the model was observed in the treatment holding the combination of $10 \mathrm{~g}$ of Napier fodder biomass, $0.2 \mathrm{~g} \mathrm{~K}_{2} \mathrm{HPO}_{4}, 0.3 \mathrm{~g} \mathrm{MgSO}_{4}$, $0.217 \mathrm{~g} \mathrm{NaCl}, 10 \mathrm{~g}$ peptone, $0.20 \mathrm{~g}$ of $\left(\mathrm{NH}_{4}\right)_{2} \mathrm{SO}_{4}$ in $1 \mathrm{l}$ of distilled water. The decrease in enzymatic activity with increasing incubation time might be due to depletion of nutrients and production of other inhibitors during the fermentation medium (Ikram-ul-Haq et al., 2005). The optimized parameters were validated practically by shake-flask experiments. The observed cellulase activity for optimized media parameters was $23.87 \mathrm{U} \mathrm{ml}^{-1}$, which is at par with the predicted cellulase activity of $23.55 \mathrm{U} \mathrm{ml}^{-1}$. The results positively correlate that the Napier fodder biomass waste could be utilized by yeast YES5, as a good source of carbon for exhibiting maximum cellulase activity. Cellulase activity using a synthetic source of carbon was $35.70 \mathrm{U} \mathrm{ml}^{-1}$ at optimal parameters. The cellulase activity using a natural source of carbon (waste Napier biomass) was 23.87 $\mathrm{U} \mathrm{ml}^{-1}$ at optimal parameters (Table 3). Statistical designs are efficient tool for enhancing cellulase production. This study focused on the optimization of medium components for obtaining maximum cellulase activity in Trichosporon asahii, while utilizing Napier biomass waste as a carbon source. The optimum cellulase activity of YES3 (Candida tropicalis) isolate, observed after optimizing factors such as $\mathrm{pH}$, temperature and incubation period was $35.53 \mathrm{U}$ (Valliammai et al., 2020). RSM provided the individual and interactive effects of components in the medium during fermentation. Peptone, ammonium chloride, yeast extract were significant components for cellulase production using Bacillus tequilensi (Sharma et al., 2015).

Napier biomass was subjected to physico-chemical characterization. The cellulose content was maximum in Napier fodder biomass (51.34\%). The lignin and hemicellulose content of Napier biomass were $19.10 \%$ and $16.70 \%$, respectively. YES5 was inoculated for the saccharification of Napier biomass waste, and its percentage of saccharification was noted at regular intervals. The samples were withdrawn at regular intervals for estimating the saccharification percentage. The maximum saccharification percentage (33.15\%) was observed on $3^{\text {rd }}$ day. Initially, the percentage of saccharification was low followed by a gradual increase, and later a declining trend was noticed (Fig. 5). Yeasts like Pichiastipitis was utilized in the saccharification study of sugarcane bagasse (Lau et al., 2010). The saccharification potential of Candida tropicalis isolate YES3 in Napier grass biomass was maximum on $3^{\text {rd }}$ day $(31.93 \%)$ (Valliammai et al., 2020).

In this study, a novel cellulolytic yeast YES5 isolated from the the forest soil was molecularly characterized as Trichosporon asahii (Mk640632). A highly reliable RSM model was developed for maximizing the YES5 cellulase activity. This study contributes an active participant YES5 to the lignocellulosic degrading family which could be a boon for the biobased industries and for the production of green chemicals like ethanol. 

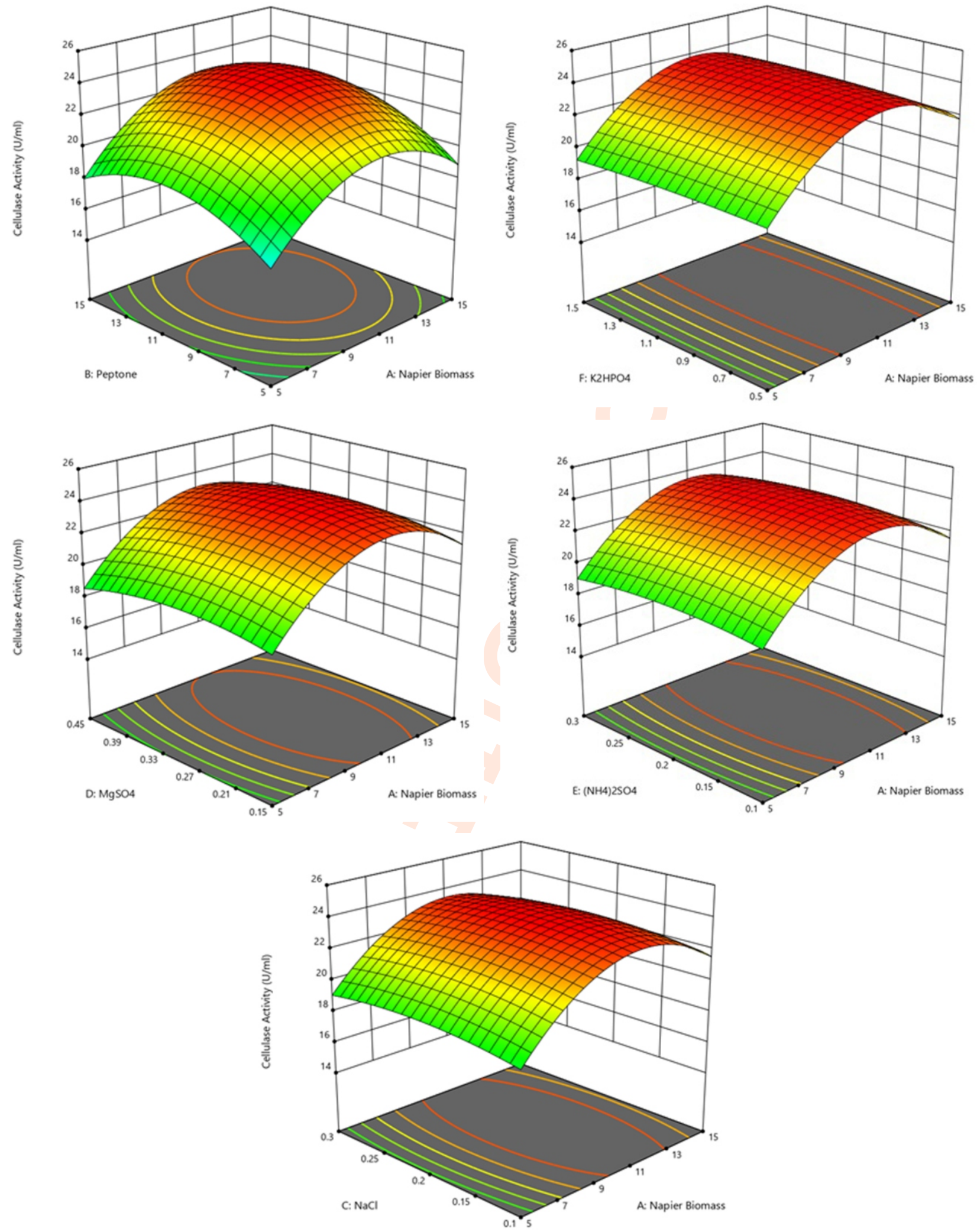

Fig. 4: RSM $3 \mathrm{D}$ plots show the effect of interactive and individual effects of parameters in cellulase activity of Trichosporon asahii YES5. (A) Effect of Napier biomass and peptone, (B) Effect of Napier biomass and dipotassium hydrogen phosphate, (C) Effect of Napier biomass and magnesium sulphate, (D) Effect of Napier biomass and Ammonium sulphate and (E) Effect of Napier biomass and sodium chloride. 


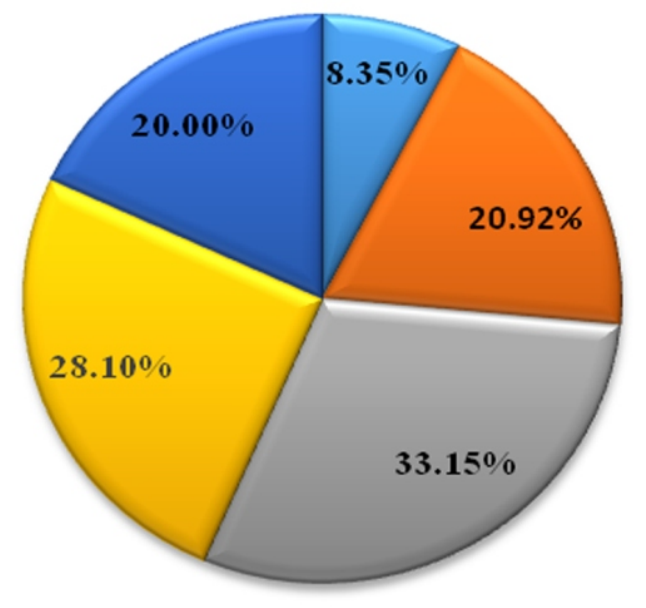

$\square$ Day1 $\square$ Day2 $\square$ Day3 $\square$ Day4 $\square$ Day5

Fig. 5: Saccharification of Napier fodder biomass by Trichosporon asahii YES5. YES5 (Trichosporon asahii) was inoculated into Napier biomass and saccharification potential was observed for 5 days.

\section{Acknowledgement}

The first Author, Meyyappan Geetha Valliammai, being an INSPIRE fellow [IF170519], is grateful to DST, INSPIRE Fellowship for the financial support.

\section{Add-on Information}

Authors' contribution: M.G. Valliammai: Performed scientific experiments and drafted the manuscript; N.O. Gopal: Planned the scientific work. He guided Meyyappan Geetha Valliammai in performing the experiments; R. Anandham: Suggested ideas for performing the scientific experiment.

Research content: The research content of manuscript is original and has not been published elsewhere.

Ethical approval: NotApplicable

Conflict of interest: The authors declare that there is no conflict of interest.

\section{Data from other sources: NotApplicable}

Consent to publish: All authors agree to publish the paper in Journal of Environmental Biology.

\section{References}

Artzi, L., E. Morag, Y. Barak, R. Lamed and E.A. Bayer: Clostridium clariflavum: Key cellulosome players are revealed by proteomic analysis. mBio., 6, e00411-00415(2015).
Baboo, B., R. Sagar, S.S. Bargali and H. Verma:Tree species composition, regeneration and diversity within the protected area of Indian dry tropical forest. Trop. Ecol., 58, 409-423 (2017).

Battaglia, E., S.F. Hansen, A. Leendertse, S. Madrid, H. Mulder, I. Nikolaev and R.P. de Vries: Regulation of pentose utilisation by AraR, but not XInR, differs in Aspergillus nidulans and Aspergillus niger. Appl. Microbiol. Biotechnol., 91, 387-397 (2011).

Bargali, K. and S.S. Bargali: Germination capacity of seeds of leguminous plants under water deficit conditions: implication for restoration of degraded lands in Kumaun Himalaya. Trop. Ecol., 57, 445-453 (2016)

Bargali, K., V. Manral, K. Padalia, S.S. Bargali, V.P. Upadhyay: Effect of vegetation type and season on microbial biomass carbon in Central Himalayan forest soils, India. Catena, 171, 125-135(2018).

Bargali, S.S., K. Padalia and K. Bargali: Effects of tree fostering on soil health and microbial biomass under different land use systems in central Himalaya. Land Degrad. Dev., 30, 1984-1998 (2019).

Bargali, S.S., S.P. Singh and R.P. Singh: Structure and function of an age series of eucalypt plantations in Central Himalaya, I. Dry matter dynamics. Ann. Bot., 69, 405-411 (1992a).

Bargali, S.S., R.P. Singh and S.P. Singh: Structure and function of an age series of eucalypt plantations in Central Himalaya, II. Nutrient dynamics. Ann. Bot., 69, 413-421 (1992b).

Bargali, S.S., R.P. Singh and M. Joshi: Changes in soil characteristics in eucalypt plantations replacing natural broad leaved forests. J. Veg. Sci., 4, 25-28 (1993).

Bhuyan, P., M.L. Khan and R.S. Tripathi: Tree diversity and population structure in undisturbed and humanimpacted stands of tropical wet evergreen forest in Arunachal Pradesh, Eastern Himalayas, India. Biodivers. Conserv., 12, 1753-1773 (2003).

Davidar, P., S. Sahoo, P.C. Mammen, P. Acharya, J.P. Puyravaud, M. Arjunan, J. P. Garrigues and K. Roessingh: Assessing the extent and causes of forest degradation in India: Where do we stand? Biol. Conserv., 143, 2937-2944 (2010).

Deka, D., P. Bhargavi, A. Sharma, D. Goyal, M. Jawed and A. Goyal: Enhancement of cellulase activity from a new strain of Bacillus subtilis by medium optimization and analysis with various cellulosic substrates. Enzyme Res., 2011, 1-8 (2011).

Dien, B., M. Cotta and T.J. effries: Bacteria engineered for fuel ethanol production: Current status. Appl. Microbiol. Biotechnol., 63, 258$266(2003)$

Gaurav, N., S. Sivasankari, G. Kiran, A. Ninawe and J. Selvin: Utilization of bioresources for sustainable biofuels: A review. Renew Sust. Energ. Rev., 73, 205-214 (2017).

Gosain, B.G., G.C.S. Negi, P.P. Dhyani, S.S. Bargali and R. Saxena: Ecosystem services of forests: Carbon Stock in vegetation and soil components in a watershed of Kumaun Himalaya, India. Int. J. Ecol. Environ. Sci., 41, 177-188 (2015)

Guo, X., R. Zhang, Z. Li, D. Dai, C. Li and X. Zhou : A novel pathway construction in Candida tropicalis for direct xylitol conversion from corncob xylan. Bioresour. Technol., 128, 547-552 (2013).

Hankin, L. and S.L. Anagnostakis: Solid media containing carboxymethylcellulose to detect $\mathrm{Cx}$ cellulase activity of microorganisms. Microbiology, 98, 109-115 (1977).

Harju, S., H. Fedosyuk and K.R. Peterson: Rapid isolation of yeast genomic DNA: Bustn'Grab. BMC Biotechnol., 4, 8 (2004).

Hendricks, C.W., J.D. Doyle and B. Hugley: A new solid medium for enumerating cellulose-utilizing bacteria in soil. Appl. Environ. Microbiol., 61, 2016-2019(1995).

Ikram-ul-Haq, M.M.J., S. Khan and T.Z. Siddiq: Cotton saccharifying activity of cellulases produced by co-culture of Aspergillus niger and Trichoderma viride. Res. J. Agric. Biol. Sci., 1, 241-245 (2005). 
Imamoglu, E. and F.V. Sukan: Scale-up and kinetic modeling for bioethanol production. Bioresour. Technol., 144, 311-320 (2013).

Karki, H., K. Bargali, S.S. Bargali, Vibhuti and Y.S. Rawat: Plant diversity, regeneration status and standing biomass under varied degree of disturbances in temperate mixed oak-conifer forest, Kumaun Himalaya. Int. J. Ecol. Environ. Sci., 43, 331-345 (2017)

Lau, M.W., C. Gunawan, V. Balan and B.E. Dale: Comparing the fermentation performance of Escherichia coli K011, Saccharomyces cerevisiae 424A (LNH-ST) and Zymomonas mobilis AX101 for cellulosic ethanol production. Biotechnol. Biofuels., 3, 11 (2010).

Lee, S.M. and Y.M. Koom: Pilot-scale production of cellulase using Trichoderma reesei Rut C-30 in fed-batch mode. J. Microbiol. Biotechn., 11, 229-233 (2001).

Lu, J., X.Li, R. Yang, L. Yang, J. Zhao, Y. Liu and Y. Qu: Fed-batch semisimultaneous saccharification and fermentation of reed pretreated with liquid hot water for bio-ethanol production using Saccharomyces cerevisiae. Bioresour. Technol., 144, 539-547 (2013).

Lu, Z., F. He, Y. Shi, M. Lu and L.Yu: Fermentative production of L (+)lactic acid using hydrolyzed acorn starch, persimmon juice and wheat bran hydrolysate as nutrients. Bioresour. Technol., 101, 3642-3648 (2010).

Manral, V., K. Bargali, S.S. Bargali and C. Shahi: Changes in soil biochemical properties following replacement of Banj oak forest with Chir pine in Central Himalaya, India. Ecol. Process., 9, 1-9 (2020).

Moon, S.H. and S.J. Parulekar: A parametric study ot protease production in batch and fed-batch cultures of Bacillus firmus. Biotechnol. Bioengg., 37, 467-483 (1991).

Mussatto, S.I., E.M. Machado, L.M. Carneiro and J.A. Teixeira: Sugars metabolism and ethanol production by different yeast strains from coffee industry wastes hydrolysates. Appl. Energy, 92, 763-768 (2012).

Queen, J.P., G.P. Quinn and M.J. Keough: Experimental design and data analysis for biologists. Cambridge University Press (2002).

Rasul, F., A. Afroz, U. Rashid, S. Mehmood, K. Sughra and N. Zeeshan: Screening and characterization of cellulase producing bacteria from soil and waste (molasses) of sugar industry. Int. J. Biosci., 6 , 230-236 (2015).

Sagar, R. and J.S. Singh: Structure, diversity and regeneration of tropical dry deciduous forest of northern India. Biodivers. Conserv., 14, 935-959 (2005).

Schwan, R.F., E.G. Almeida, M.A.G. Souza-Dias and L. Jespersen: Yeast diversity in rice, cassava fermentations produced by the indigenous Tapirapé people of Brazil. FEMS Yeast Res., 7, 966972(2007)

Shariq, M. and M. Sohail: Application of Candida tropicalis MK-160 for the production of xylanase and ethanol. J. King Saud Univ. Sci., 31, 1189-1194 (2018).

Sharma, A., R. Tewari and S. Soni: Application of statistical approach for optimizing CMCase production by Bacillus tequilensis S28 strain via submerged fermentation using wheat bran as carbon source. Int. J. Biol. Biomol. Agric. Food Biotechnol. Engin., 9, 76-86 (2015).

Singh, D. and G. Kaur: Optimization of different process variables for the production of an indolizidine alkaloid, swainsonine from Metarhizium anisopliae. J. Basic. Microbiol., 52, 590-597 (2012).

Sluiter, A., B. Ruiz, R. Ruiz, C. Scarlata, J. Sluiter, D. Templeton and D. Crocker: Determination of structural carbohydrates and lignin in biomass. NREL/TP-510-42618 (2012).

Sukumaran, R.K., R.R. Singhania and A. Pandey: Microbial cellulasesproduction, applications and challenges. J. Scilnd. Res., 64, 834-844 (2005).

Tai, S.K, H.P.P. Lin, J. Kuo, J.K. Liu: Isolation and characterization of a cellulolytic Geobacillus thermoleovorans T4 strain from sugar refinery wastewater. Extremophiles, 8, 345-349 (2004).

Uma, C., C. Muthulakshmi, D. Gomathi and V. Gopalakrishnan: Production of ethanol from sugarcane bagasse. Res. J. Microbiol., 5, 980-985 (2010).

Vadala, B. S., S. Deshpande and A. Apte-Deshpande: Soluble expression of recombinant active cellulase in $E$. coli using $B$. subtilis (natto strain) cellulase gene. J. Genet. Eng. Biotechnol., 19, 1-7 (2021).

Valliammai, M.G., N.O. Gopal and R. Anandham: Mining the prospective of Candidatropicalis YES3 in Napier biomass saccharification. Biomass Convers. Bior., 10, 1-11 (2020).

Valliammai, M.G., N.O. Gopal and R. Anandham: Elucidation of microbial diversity and lignocellulolytic enzymes for the degradation of lignocellulosic biomass in the forest soils of Eastern and Western Ghats of Tamil Nadu, India. Biofuel. Bioprod. Biorefin., 15, 47-60 (2021).

Vanhala, P., I. Bergström, T. Haaspuro, P. Kortelainen, M. Holmberg and M. Forsius: Boreal forests can have a remarkable role in reducing greenhouse gas emissions locally: Land use-related and anthropogenic greenhouse gas emissions and sinks at the municipal level. Sci. Total Environ., 557, 51-57 (2016).

Wang,Y., X. Fang, F. An, G. Wang and X. Zhang: Improvement of antibiotic activity of Xenorhabdus bovienii by medium optimization using response surface methodology. Microb. Cell Fact., 10, 98 (2011).

Wood, T.M. and K.M. Bhat: Methods for measuring cellulase activities. Method Enzymol., 160, 87-112 (1988).

Woodard, K. and G. Prine: Regional performance of tall tropical bunchgrasses in the South-eastern USA. Biomass Bioenerg., 5, 321 (1993). 